\title{
ЕКСПЕРИМЕНТАЛЬНЕ ДОСЛІДЖЕННЯ ДОБОВОГО АКУМУЛЮВАННЯ ХОЛОДУ ШЛЯХОМ ВИКОРИСТАННЯ ВОДИ ПІДЗЕМНИХ ГОРИЗОНТІВ М. КИЕВА
}

\author{
${ }^{1}$ Інститут відновлюваної енергетики НАН України, \\ 02094,м. Київ, вул. Гната Хоткевича, 20А \\ ${ }^{2}$ Інститут технічної теплофізики НАН України \\ 03057, м. Київ, вул. Марії Капніст (Желябова), 2а
}

Ю.П.Морозов ${ }^{1}$, доктор технічних наук, Д.М.Чалаєв ${ }^{1,2}$, кандидат технічних наук, В.Г. Олійніченко ${ }^{1}$, В.В. Величко

Викладено результати експериментального дослідження ефективності використання добового акумулятора холодної води для забезпечення роботи серійного фанкойлу з метою забезпечення кондиціювання повітря в окремому приміщенні.

Натурна експериментальна установка містить видобувну свердловину, поглинальну свердловину, баки-акумулятори, витратомір, термометр холодної води, термометр повітря в приміщенні, мережевий насос, термометр відпрацьованоі води, приміщення для охолодження, фанкойл.

Вода з температурою $12^{\circ} \mathrm{C}$ з видобувної свердловини подається свердловинним насосом в групу накопичувальних баків, які є акумулятором холоду. Після накопичення води в баках вмикається мережевий насос, який подає воду з накопичувальних баків на фанкойли. Вода, яка пройшла через фанкойли та віддала холод в приміщення, надходить до поглинальної свердловини.

Метою експерименту є дослідження системи акумулювання холодної води в якості добового акумулювання холоду та ї подальшого використання для забезпечення комфортних умов в приміщенні за допомогою серійного фанкойлу.

Основні характеристики проведення експерименту: дебіт води на виході з підйомної свердловини становить 0,9 кг/с, дебіт води,

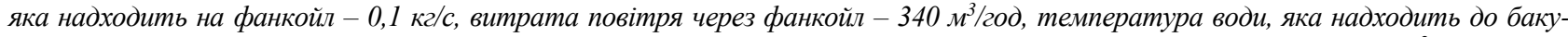
акумулятору $-12^{\circ} \mathrm{C}$, температура води, що надходить до фанкойлу $-12,5^{\circ} \mathrm{C}$, площа охолодження примімення - $20 \mathrm{M}^{2}$, початкова температура в приміщенні $-28^{\circ} \mathrm{C}$, кількість баків-акумуляторів - 7 ит., загальний об' 'м баків-акумуляторів- $7 \mathrm{M}^{3}$.

В результаті проведених експериментів досягнуто зниження температури в приміщенні до $23^{\circ} \mathrm{C}$ за 3 години роботи фанкойла. Встановлено, в прочесі охолодження приміщення холодопродуктивність фанкойла змінювалася від 3640 Вт в початковий період до $1820 \mathrm{Bm}$ - в кінці. Температури холодоносія на виході з фанкойла при цьому становили, відповідно, $21,5^{\circ} \mathrm{C}$ i $17,1^{\circ} \mathrm{C}$. Дослідження показали, щзо система акумулювання води підземних горизонтів з початковою температурою води $12^{\circ} \mathrm{C}$ ефективно працює в режимі охолодження приміщення з застосуванням серійних фанкойлів. Акумулятори теплоти у вигляді баківакумуляторів ефективно використовуються також в якості буферних ємностей для регулювання подачі води в фанкойли. $B$ баках-акумуляторах при вистойці води більше 2-х діб спостерігається накопичення твердих осадів. Розбіжність розрахункових значень температури з експериментальними значеннями не перевищує 5-7\%. Система потребує подальшої модернізаціі для автоматичного заміру параметрів води і температури та вологості приміщення. Бібл. 13, рис. 7.

Ключові слова: акумулятор холодної води, добувна свердловина, поглинальна свердловина, фанкойл, кондиціювання приміщень, бак-акумулятор, мережевий насос

\section{EXPERIMENTAL INVESTIGATION OF DAILY COLD ACCUMULATION BY WATER USE OF UNDERGROUND HORIZONS IN KIEV}

\author{
Yu. Morozov ${ }^{1}$, doctor of technical sciences, D. Chalaev ${ }^{\mathbf{1}, 2}$, candidate of technical sciences, V. Olijnichenko', V. Velychko \\ ${ }^{1}$ Institute of Renewable Energy of the National Academy of Sciences of Ukraine \\ 02094, Kyiv, st. Hnat Hotkevich, 20A, \\ ${ }^{2}$ Institute of Technical Thermophysics of the National Academy of Sciences of Ukraine \\ 03057, Kyiv, st. Maria Kapnist (Zhelyabova), 2a
}

The results of an experimental study of the effectiveness of the use of a daily cold water battery for the production of serial fan coil in order to provide air conditioning in a separate room are presented.

The in-situ experimental unit contains a production well, an absorption well, storage tanks, a flowmeter, a cold water thermometer, an indoor air thermometer, a network pump, a waste water thermometer, a cooling room, and a fan coil.

Water with a temperature of $12^{\circ} \mathrm{C}$ from the production well is fed by a downhole pump to a group of storage tanks, which are a battery of cold. After the water has accumulated in the tanks, a network pump is switched on, which supplies water from the storage tanks to the fan coils. The water that passed through the fan coils and cooled the room enters the absorption well.

The purpose of the experiment is to investigate the cold water storage system as a daily accumulation of cold water and its subsequent use to provide comfortable indoor conditions with the help of serial fan coil.

The main characteristics of the experiment: the flow rate of water at the outlet of the well is $0.9 \mathrm{~kg} / \mathrm{s}$, the flow rate of water entering the fancoil $-0.1 \mathrm{~kg} / \mathrm{s}$, the flow rate of air through the fancoil $-340 \mathrm{~m}^{3} / \mathrm{h}$, the flowing water temperature to the storage tank $-12^{\circ} \mathrm{C}$, the temperature of the water entering the fan coil $-12,5^{\circ} \mathrm{C}$, the cooling area of the room - $20 \mathrm{~m}^{2}$, the initial temperature in the room $28^{\circ} \mathrm{C}$, the number of storage tanks -7 pcs., the total volume of the storage tanks $-7 \mathrm{~m}^{3}$.

As a result of the experiments, the room temperature was reduced to $23^{\circ} \mathrm{C}$ for 3 hours of fancoil operation. The cooling capacity of the fan coil was found to vary from 3640 watts in the initial period to 1820 watts at the end of the cooling process. The temperatures of the coolant at the outlet of the fan coil were $21.5^{\circ} \mathrm{C}$ and $17.1^{\circ} \mathrm{C}$, respectively.

(C) Ю.П.Морозов, Д.М.Чалаєв, В.Г. Олійніченко, В.В. Величко, 2019 
Studies have shown that the water storage system of underground horizons with an initial water temperature of $12^{\circ} \mathrm{C}$ works effectively in the cooling mode of the room using serial fan coils. Heat storage tanks in the form of storage tanks are also effectively used as buffer tanks for regulating the supply of water to the fan coils. Accumulation of solid sediments is observed in the storage tanks when the water is stored for more than 2 days. The discrepancy between the calculated values of the temperature and the experimental values does not exceed 5-7\%. The system needs further upgrading to automatically measure water parameters and room temperature and humidity. Ref. 13, fig. 7.

Keywords: cold water accumulator, extraction well, absorption well, fancoil, room air conditioning, storage tank, circulation pump.

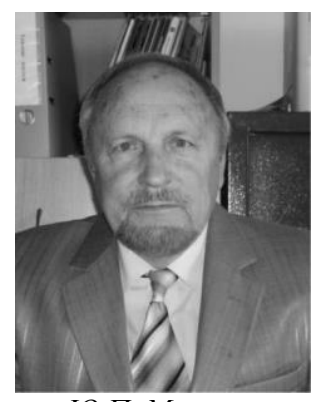

Ю.П. Морозов Yu. Morozov

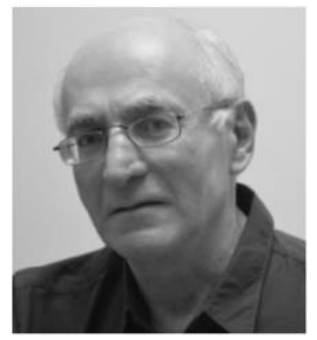

Д.М. Чалаєв D. Chalaev

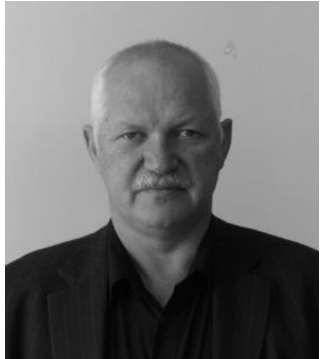

В.Г. Олійніченко V. Olijnichenko

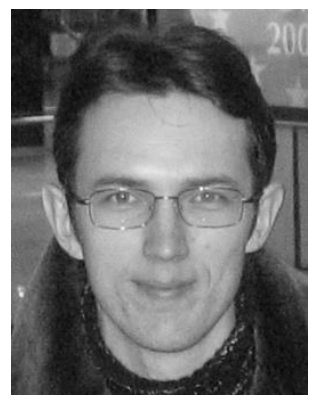

B.B. Величко

V. Velychko
Відомості про автора: зав. Відділом геотермальної енергетики Інституту відновлюваної енергетики НАН України, доктор технічних наук, старший науковий співробітник.

Освіта: Національний технічний університет України «Київський політехнічний інститут імені Ігоря Сікорського».

Наукова сфера: відновлювана енергетика, геотермальна енергетика, використання тепла довкілля.

Публікації: біля 160

ORCID: 0000-0003-1632-9735

Контакти: тел./факс +38 (044) 206-28-09

e-mail: geotherm@ukr.net

Відомості про автора: Старший науковийспівробітниквідділугеотермальноїенергетикиІнститутувідновлюваноїенергетики НАН України, кандидат технічних наук. Провідний науковий співробітник відділу тепломасообміну в дисперсних системах Інституту технічної теплофізики НАН України.

Освіта: Московський технологічний інститут м'ясної і молочної промисловості.

Наукова сфера: відновлювані джерела енергії, теплові насоси, енергозбереження.

Публікації: біля 100.

ORCID: 0000-0002-5154-4257

Контакти: тел.+38 (044) 209-07-68

e-mail: chalaev@i.ua

Відомості про автора: науковий співробітник відділу геотермальної енергетики Інституту відновлюваної енергетики НАН України.

Освіта: Київський технологічний інститут харчової промисловості.

Наукова сфера: відновлювана енергетика, геотермальна енергетика, використання тепла довкілля.

Публікації: 67.

ORCID: 0000-0003-4651-9628

Контакти: тел./факс +38 (044) 206-28-09

e-mail: geotherm@ukr.net

Відомості про автора: науковий співробітник відділу геотермальної енергетики Інституту відновлюваної енергетики НАН України.

Освіта: Київський Національний університет будівництва та архітектури, факультет теплогазопостачання, вентиляції та охорони навколишнього середовища.

Наукова сфера: відновлювана енергетика, геотермальна енергетика, використання тепла довкілля.

Публікації: 58 .

ORCID: 0000-0001-9979-0994

Контакти: тел./факс +38 (044) 206-28-09

e-mail: geotherm@ukr.net
Author information: Head of the Department of Geothermal Energy of the Institute of Renewable Energy of the National Academy of Sciences of Ukraine, doctor of technical sciences, senior researcher.

Education: National Technical University of Ukraine "Igor Sikorsky Kyiv Polytechnic Institute".

Research area: renewable energy, geothermal energy, use of environmental heat.

Publications: about 160.

ORCID: 0000-0003-1632-9735

Contacts: phone/fax +38 (044) 206-28-09

e-mail: geotherm@ukr.net

Author information: Senior Researcher of the Department of Geothermal Energy of the Institute of Renewable Energy of NAS of Ukraine, $\mathrm{Ph} . \mathrm{D}$. (engineering). Leading Researcher of the Department of Heat and Mass Transfer in Disperse Systems of the Institute of Engineering Thermophysics of NAS of Ukraine.

Education: Moscow Technological Institute of Meat and Dairy Industry.

Research area: renewable energy sources, heat pumps, energy saving.

Publications: about 100.

ORCID: 0000-0002-5154-4257

Contacts: phone+38 (044) 209-07-68

e-mail: chalaev@i.ua

Author information: researcher at Geothermal Energy Department, Institute of Renewable Energy of National Academy of Sciences of Ukraine.

Education: Kiev Technological Institute of Food Industry.

Research area: renewable energy, geothermal energy, use of environmental heat.

Publications: 67.

ORCID: 0000-0003-4651-9628

Contacts: phone/fax +38 (044) 206-28-09

e-mail: geotherm@ukr.net

Author information: researcher at Geothermal Energy Department, Institute of Renewable Energy of National Academy of Sciences of Ukraine.

Education: Kyiv National University of Civil Engineering and Architecture, Faculty of heat and gas supply, ventilation and environmental protection.

Research area: renewable energy,

geothermal energy, use of environmental heat.

Publications: 58.

ORCID: 0000-0001-9979-0994

Contacts: phone/fax +38 (044) 206-28-09

e-mail: geotherm@ukr.net 
Вступ. Основна частина енергоспоживання житлових і громадських будівель припадає на опалення приміщень в зимовий час і кондиціонування повітря влітку. В останні роки, завдяки різним заходам 3 енергозбереження, в комунальному секторі досягнуто суттєве зниження витрати енергії на опалення. Але, разом 3 тим, 3 кожним роком зростає споживання енергії на кондиціювання повітря в літній період, що пов'язано зі збільшенням кількості спекотних днів внаслідок глобальної зміни клімату [1].

У традиційних системах кондиціонування в основному використовуються парокомпресійні холодильні машини. Введення міжнародної заборони на використання несприятливих для навколишнього середовища озоноруйнуючих холодоагентів послужило стимулом для розвитку нових екологічно чистих технологій охолодження [2]. Ефективним напрямком вирішення цих завдань $\epsilon$ використання в якості джерела «природного охолодження» грунтових вод, температура яких протягом всього року не піднімається вище за $10-12^{\circ} \mathrm{C}$. Така система відрізняється високою економічністю та простотою - «холод» зі свердловини напряму надходить до системи кондиціювання $[3,4]$.

Підтримка комфортної температури повітря в приміщенні може бути забезпечена шляхом використання різних технічних засобів та використання теплоносіїв.

За останні роки для систем охолодження в якості робочої речовини використовується вода $[5,6]$. Найбільш розповсюдженими серед них $\epsilon$ «холодні стелі». На відміну від традиційних кондиціонерів повітря такі системи мають більш високі капітальні затрати, але потребують суттєво менших поточних витрат.

Одним з варіантів забезпечення комфортних умов в приміщеннях $є$ паралельне підключення системи «пасивного» кондиціонування до фанкойлів, які використовуються в теплонасосних установках «повітря-вода». При цьому тепловий насос «повітря-вода» не працює і до фанкойлів в якості холодоносія надходить вода зі свердловин 3 температурою $+12^{\circ} \mathrm{C}$, що в системах «пасивного» кондиціонування є достатнім для підтримання в приміщенні температури 24$25^{\circ} \mathrm{C}$. Тепловий насос, який здатний охолоджувати холодоносій до $+7^{\circ} \mathrm{C}$, вмикається тільки в екстремально жаркі дні.

Авторами досліджувалась установка використання вертикального грунтового теплообмінника разом 3 фанкойлом для кондиціонування приміщення влітку [7], де вертикальна свердловина глибиною 20 м забезпечувала зниження температури в приміщенні на $5^{\circ} \mathrm{C}$ при розрахунковій температурі повітря на кондиціонівання в теплий період року $28,7^{\circ} \mathrm{C}$ та робочих температуpax холодоносія $12-17^{\circ} \mathrm{C}$. В процесі експлуатації установки відбувалось відновлення температурного поля вертикальної свердловини влітку для підготовки до видобування низькопотенційного тепла взимку.

Експериментальна система теплохолодопостачання Міжнародного центру відновлюваної енергетики НАН України містить декілька підсистем, які підключені до загального контуру циркуляції теплоносія та можуть працювати як окремо, так і доповнювати одна іншу.

Добове акумулювання теплоти або холоду призначається для забезпечення необхідними коливаннями температури в різний період часу дня.

Постановка завдання. При роботі фанкойла на воді зі свердловини температури холодоносія відрізняються від проектних вимог системи кондиціонування, тому експериментальні дослідження виконуються з метою:

1. Дослідження ефективності використання серійних фанкойлів, які призначені, в основному, для опалення приміщень.

2. Дослідження системи акумулювання холодної води в якості добового акумулювання холоду та її подальшого використання для забезпечення комфортних умов в приміщенні за допомогою серійного фанкойлу.

3. Дослідження ефективності використання серійних фанкойлів для забезпечення кондиціювання приміщень.

Опис експериментальної установки. Принципову схему експериментальної установки, розміщення експериментального обладнання та розташування свердловин наведено на рис. 1. 


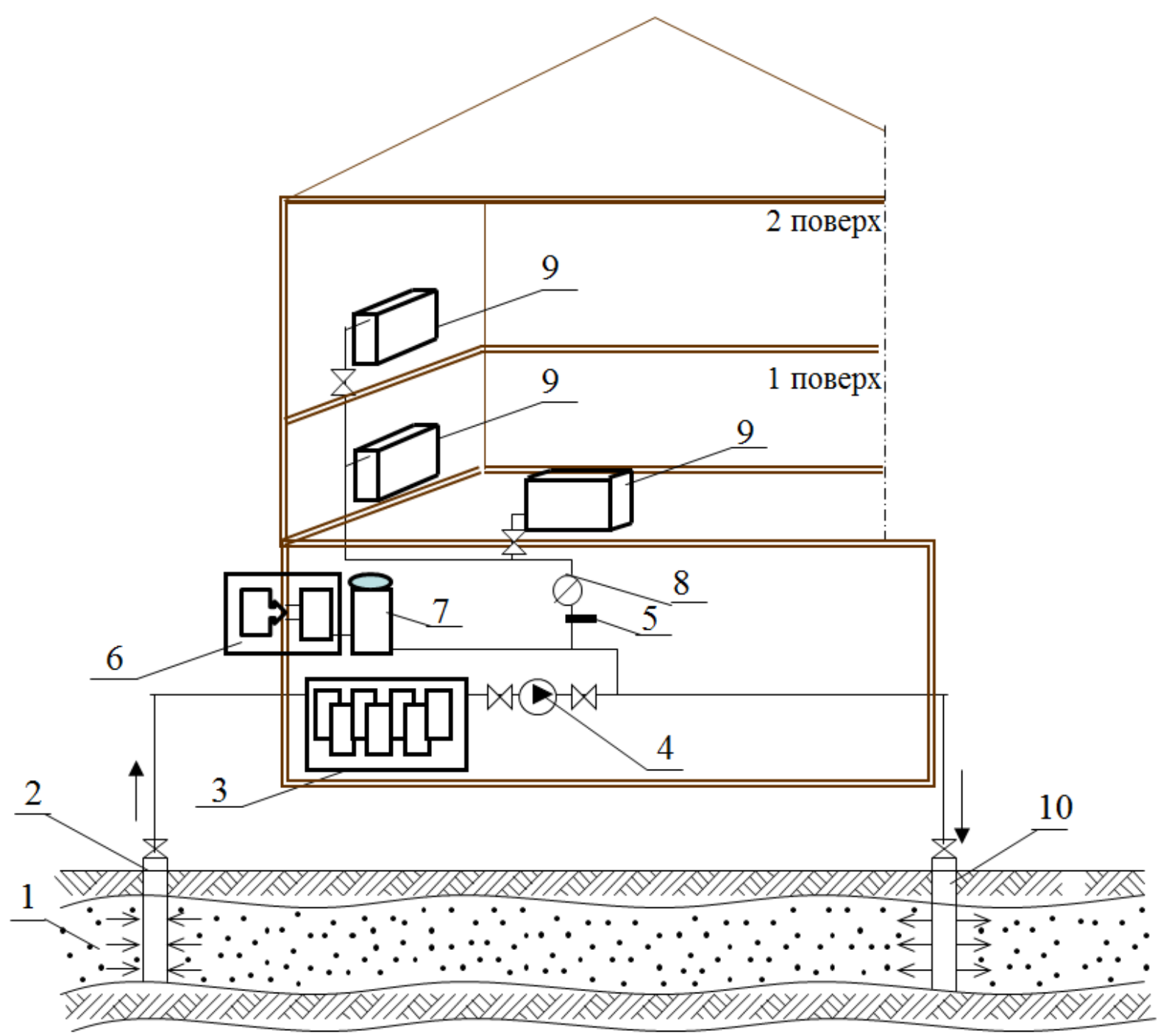

Рис. 1. Принципова схема експериментальної установки, розміщення експериментального обладнання та розташування свердловин: 1 - проникний підземний шар; 2 - видобувна свердловина; 3 - баки-акумулятори (7 шт.); 4 - насосна станція; 5 - термометр ХВ (холодної води); 6- тепловий насос типу “повітря-вода"; 7 - бак-акумулятор теплового насоса; 8 -лічильник тепла; 9 - фанкойл (3 шт.); 10 - поглинальна свердловина.

Fig. 1. Schematic diagram of the experimental installation, placement of experimental equipment and location of wells: $1-$ underground permeable layer; 2 - production well; 3 -storage tanks ( 7 pcs.); 4 - pumping station; 5 - thermometer CW (cold water); 6 -air-to-water heat pump; 7 -tank-accumulator of the heat pump; 8 -heat meter; 9 -fancoil (3 pcs.); 10 -injection well.

Натурна експериментальна установка дослідження добового акумулювання холоду шляхом використання води підземних горизонтів (рис. 1) містить проникний підземний шар, видобувну свердловину, 7 баків-акумуляторів, насосну станцію, термометр холодної води, тепловий насос типу “повітря-вода", бак-акумулятор теплового насосу, лічильник тепла, 3 фанкойли та поглинальну свердловину.

Принцип роботи. Вода 3 температурою $12^{\circ} \mathrm{C}$ з видобувної свердловини подається свердловинним насосом в групу накопичувальних баків, які $є$ акумулятором холоду. Після нако- пичення води в баках вмикається насосна станція, яка подає воду з накопичувальних баків на фанкойли. Вода, яка пройшла через фанкойли та віддала холод в приміщення, надходить до поглинальної свердловини.

Свердловини знаходяться на відстані декількох десятків метрів одна від одної, що виключає взаємний вплив теплого і холодного "дзвонів" і наземно з'єднані між собою трубопроводом 3 включеним туди теплообмінником.

Фото бака-акумулятора наведено на рис. 2, фото мережевого насосу - на рис. 3, фанкойлу - на рис. 4. 


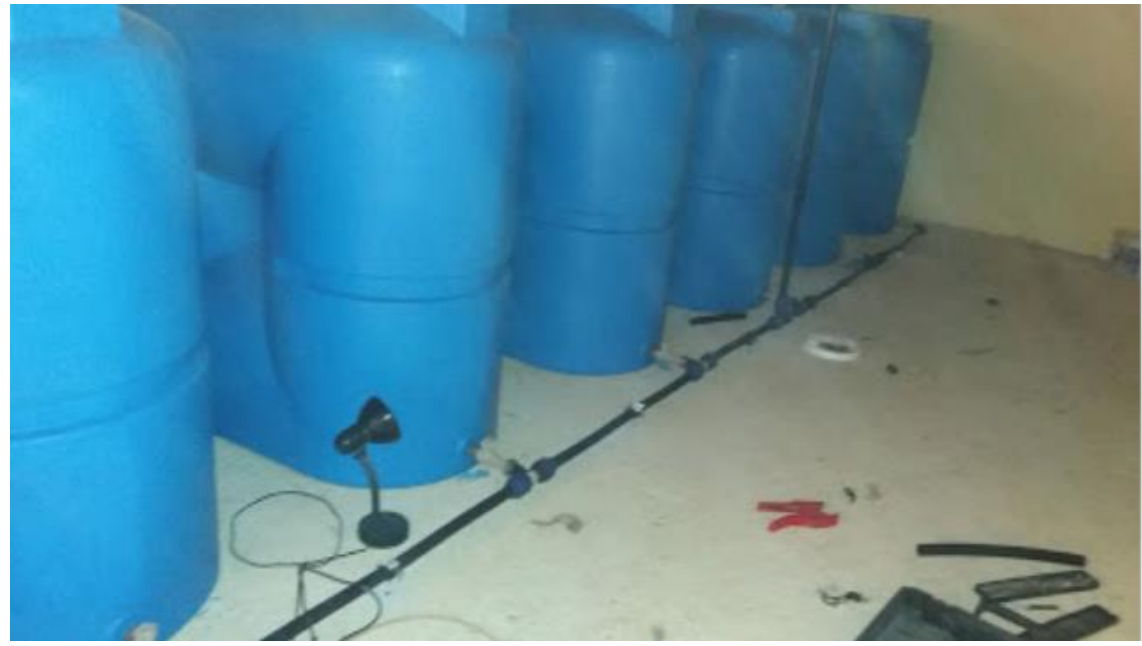

Рис. 2. Бак-акумулятор.

Fig. 2. Battery tank.

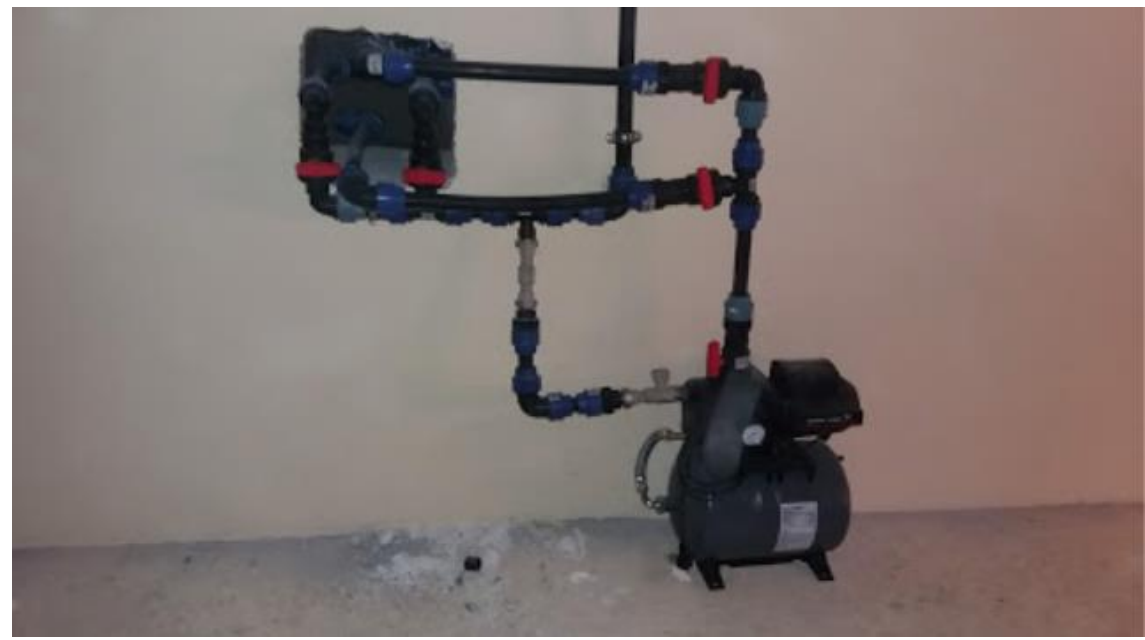

Рис. 3.Мережевий насос.

Fig. 3. Circulation pump.

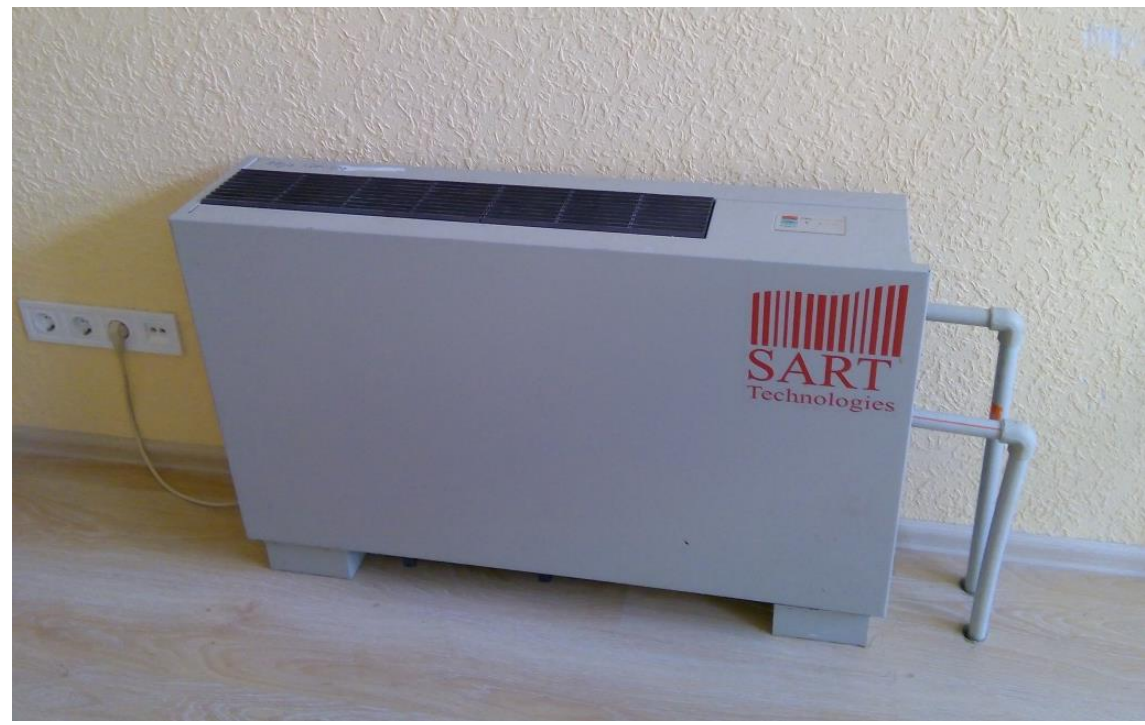

Рис. 4. Фанкойл SP200L/RM.

Fig. 4. Fancoil SP200L / RM. 
Проведення експериментальних робіт та результати досліджень. Навантаження на систему кондиціонування нерівномірна протягом дня. Тому, для забезпечення стабільного режиму відкачування води 3 добувної свердловини системи пасивного кондиціонування створена установка акумулювання холоду, яка представляє собою групу теплоізольованих ємностей загальним обсягом $\mathrm{V}_{\mathrm{a}}=7000$ л, в які закачується вода зі свердловин. Підземні водоносні горизонти представляють собою піщаники, тому при зміні режиму добування води пісок захватується потоком води і може потрапити до системи охолодження. Група акумулюючих ємностей в даному випадку буде грати роль відстійника механічних домішок та допоможе запобігти забрудненню системи.

За паспортними даними на фанкойл SP200L/RM його холодопродуктивність складає $\mathrm{Q}_{0}=2020$ Вт при витратах холодоносія $\mathrm{G}=348$ кг/год., температурі холодоносія на вході до фанкойлу $\mathrm{t}_{1 \mathrm{x}}=7^{\circ} \mathrm{C}$, на виході $-\mathrm{t}_{2 \mathrm{x}}=12^{\circ} \mathrm{C}$ і наступних параметрах повітря в приміщенні: температура по сухому термометру $\mathrm{t}_{\mathrm{A}}=27^{\circ} \mathrm{C}$, температура по мокрому термометру $\mathrm{t}_{\mathrm{AM}}=19,5^{\circ} \mathrm{C}$.

Холодопродуктивність фанкойлу можна розрахувати, використовуючи наступні залежності:

$$
\begin{aligned}
& Q_{0}=k \cdot F \cdot \Delta t, \\
& Q_{0}=c_{x} \cdot G \cdot\left(t_{2 x}-t_{1 x}\right), \\
& Q_{0}=c_{n} \cdot L \cdot\left(t_{A}-t_{B}\right),
\end{aligned}
$$

де $k$ - коефіцієнт теплопередачі між холодоносі$\epsilon м$ та повітрям; $F$ - площа теплообмінної поверхні фанкойлу; $\Delta t$ - температурний напір між холодоносієм та повітрям; $c_{x}, c_{n}$ - теплоємність холодоносія та повітря; $G$ - масові витрати холодоносія; $L$ - масові витрати повітря; $t_{l x}, t_{2 x}$ - температури рідкого холодоносія на вході та виході фанкойлу; $t_{A}, t_{B}-$ температури повітря, що охолоджується, на вході та виході фанкойлу.

Для фанкойлу, що досліджується, значення коефіцієнту теплопередачі в апараті та площа теплообмінної поверхні в формулі 1 не відомі. Однак, знаючи холодопродуктивність фанкойла в штатному режимі роботи і приймаючи до уваги, що при стабільному характері руху холодоносія та повітря ці величини не міняються $(k \cdot F=\mathrm{const})$, можна розрахувати холодопродуктивність фанкойлу при температурах холодоносія, котрі відрізняються від паспортних даних. Холодопродуктивність буде змінюватись пропорційно зміні температурного напору $\Delta t$ між холодоносієм та повітрям.

$$
Q_{0}^{\prime}=Q_{0} \cdot \frac{\Delta t^{\prime}}{\Delta t} .
$$

Процес обробки вологого повітря та зміна параметрів його стану при проходженні крізь теплообмінну поверхню фанкойлу відображені на рис. 5.

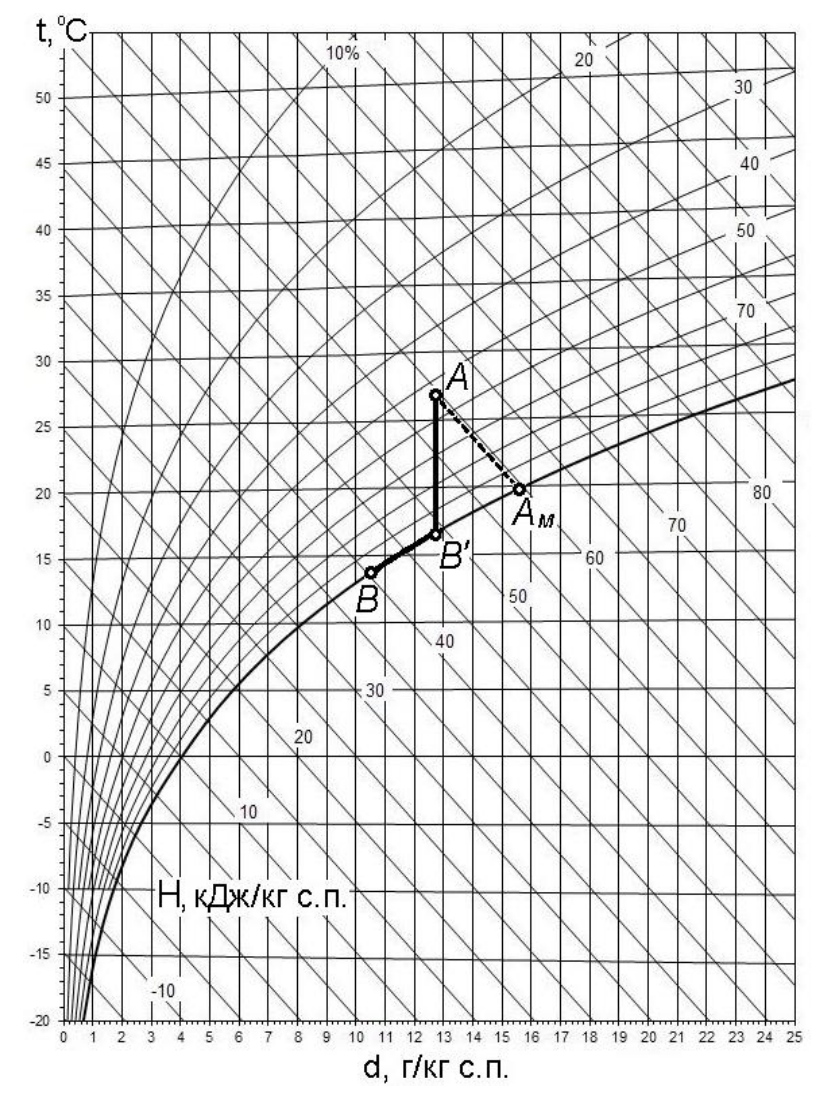

Рис. 5. Процес охолодження повітря у фанкойлі в Н-d діаграмі точка $\boldsymbol{A}$ - стан повітря на вході у фанкойл, точка $B^{\prime}$ - тепловологістні параметри повітря при охолодженні до точки роси, $B$ - стан повітря на виході з фанкойлу.

Fig. 5. The process of cooling the air in the fan coil in H-d diagram point $A$ - the state of the air at the inlet of the fan coil, point B' - thermologic parameters of air when cooled to the dew point, $B$ - the state of the air at the exit of the fan coil.

Розрахуємо основні параметри стану повітря на вході в фанкойл (точка А на рис. 5). Розрахункові формули для знаходження цих параметрів [8]:

Тепловміст (ентальпія) вологого повітря на вході у фанкойл

$$
\begin{gathered}
H_{A}=H_{A u}=1,005 \cdot t_{A M}+ \\
+\left(2500+1,8068 \cdot t_{A M}\right) \cdot 10^{-3} \cdot d_{A M}
\end{gathered} .
$$

Вологовміст насиченого вологого повітря при температурі $t_{A M}$ 


$$
d_{A \mu}=622 \cdot \frac{P_{n \mu}}{P_{\sigma}-P_{n \mu}},
$$

де $P_{\sigma}=94500$ Па - барометричний тиск; $P_{n н}=$ 2265,4 Па - парціальний тиск насиченої водяної пари при температурі $t_{A м}[9]$.

Вологовміст вологого повітря на вході у фанкойл визначаємо 3 (5)

$$
d_{A}=\frac{H_{A}-1,005 \cdot t_{A}}{2500+1,8068 \cdot t_{A}} .
$$

Результати розрахунку:

$$
\begin{gathered}
d_{A u}=622 \cdot \frac{2265,4}{94500-2265,4}=15,28 \text { г/кг с.п. } \\
H_{A}=H_{A u}=1,005 \cdot 19,5+ \\
+(2500+1,8068 \cdot 19,5) \cdot 10^{-3} \cdot 15,28=58,34 \text { кДж/кгс.п. } \\
d_{A}=\frac{H_{A c}-1,005 \cdot 27}{2500+1,8068 \cdot 27}=12,73 \text { г/кг с.п. }
\end{gathered}
$$

Виходячи 3 величини номінальної холодопродуктивності фанкойлу, розраховуємо тепловологістні параметри охолодженого повітря на виході (точка $B$ на рис. 5).

Ентальпія повітря на виході з фанкойлу

$$
\begin{gathered}
H_{B}=H_{A}-\frac{Q_{0}}{L}=58,34- \\
-\frac{2,02}{0,114}=40,62 \text { кДж/кг с.п. }
\end{gathered}
$$

H-d діаграма (рис. 5) показує, що у фанкойлі відбувається охолодження та часткове осушення повітря. Спочатку повітря при постійному вологовмісті охолоджується до точки роси (процес $A$ $B$ ), після чого доохолоджується по лінії $\varphi=100 \%$ зі зменшенням вологовмісту (процес $B^{\prime}-B$ ).

Для визначення температури повітря в точці $B$ скористаємось рівнянням залежності ентальпії від температури насиченого вологого повітря (при $\varphi=100 \%$ ). Данна розрахункова формула отримана нами шляхом апроксимації графіку $t_{m}=$ $f(H)$, який побудовано в інтервалі температур 12 $17^{\circ} \mathrm{C}$ з використанням табличних даних $[9,10]$. Залежність (9) забезпечує достатню для інженерних розрахунків ступінь точності та може бути застосована при проектуванні систем кондиціонування і осушення повітря [11].

$$
t_{B}=0,3483 \cdot H_{B}-0,3572=13,8^{\circ} \mathrm{C} .
$$

При даній температурі вологовміст насиченого вологого повітря на виході з фанкойлу буде дорівнювати

$$
\begin{gathered}
d_{B}=622 \cdot \frac{P_{n u}}{P_{\sigma}-P_{n \mu}}=622 \cdot \frac{1576,3}{94500-1576,3}= \\
=10,55 \text { г } / \text { кг с.п. }
\end{gathered}
$$

де $P_{n н}=1576,3$ Па - парціальний тиск насиченого водяної пари при температурі $t_{B}[12]$.

Рух потоків (повітря та холодоносія) у фанкойлі відбувається за перехрестно-протиточною схемою, а розрахунковий середньологарифмічний температурний напір між потоками в даному випадку дорівнює

$$
\Delta t=\frac{\left(t_{A}-t_{2 x}\right)-\left(t_{B}-t_{1 x}\right)}{\operatorname{Ln} \frac{t_{A}-t_{2 x}}{t_{B}-t_{1 x}}} .
$$

Таким чином, при роботі фанкойлу SP200L/RM в номінальному режимі з холодопродуктивністю $\mathrm{Q}_{0}=2020$ Вт величина температурного напору становить

$$
\Delta t=\frac{(27-12)-(13,8-7)}{\operatorname{Ln} \frac{27-12}{13,8-7}}=10,4{ }^{\circ} \mathrm{C} .
$$

Знаючи $\Delta t$, , 3 (1) можна знайти значення комплексу $(k \cdot F)$ для даного фанкойлу

$$
(k \cdot F)=\frac{Q_{0}}{\Delta t}=\frac{2020}{10,4}=194 \mathrm{BT} /{ }^{\circ} \mathrm{C} .
$$

Як було вказано вище, при незмінних режимах руху потоків холодоносія та повітря через фанкойл, значення $(k \cdot F)$ не змінюється і холодопродуктивність фанкойлу залежить тільки від величини температурного напору в теплообміннику. Враховуючи це, можна розрахувати холодопродуктивність фанкойлу при різних температурах холодоносія.

Результати розрахунку при температурі повітря на вході до фанкойлу $27^{\circ} \mathrm{C}$ наведені на рис. 6. Як видно з графіку, при роботі фанкойлу з використанням в якості холодоносія 12-ти градусної води зі свердловини, його холодопродуктивність становить близько 80\% від номінальної.

Час автономної роботи одного фанкойлу за рахунок використання води, накопиченої в акумулюючих ємностях, складає

$$
\tau=Q_{0} \cdot \frac{V_{a}}{G}=\frac{7000}{348}=20 \text { годин. }
$$




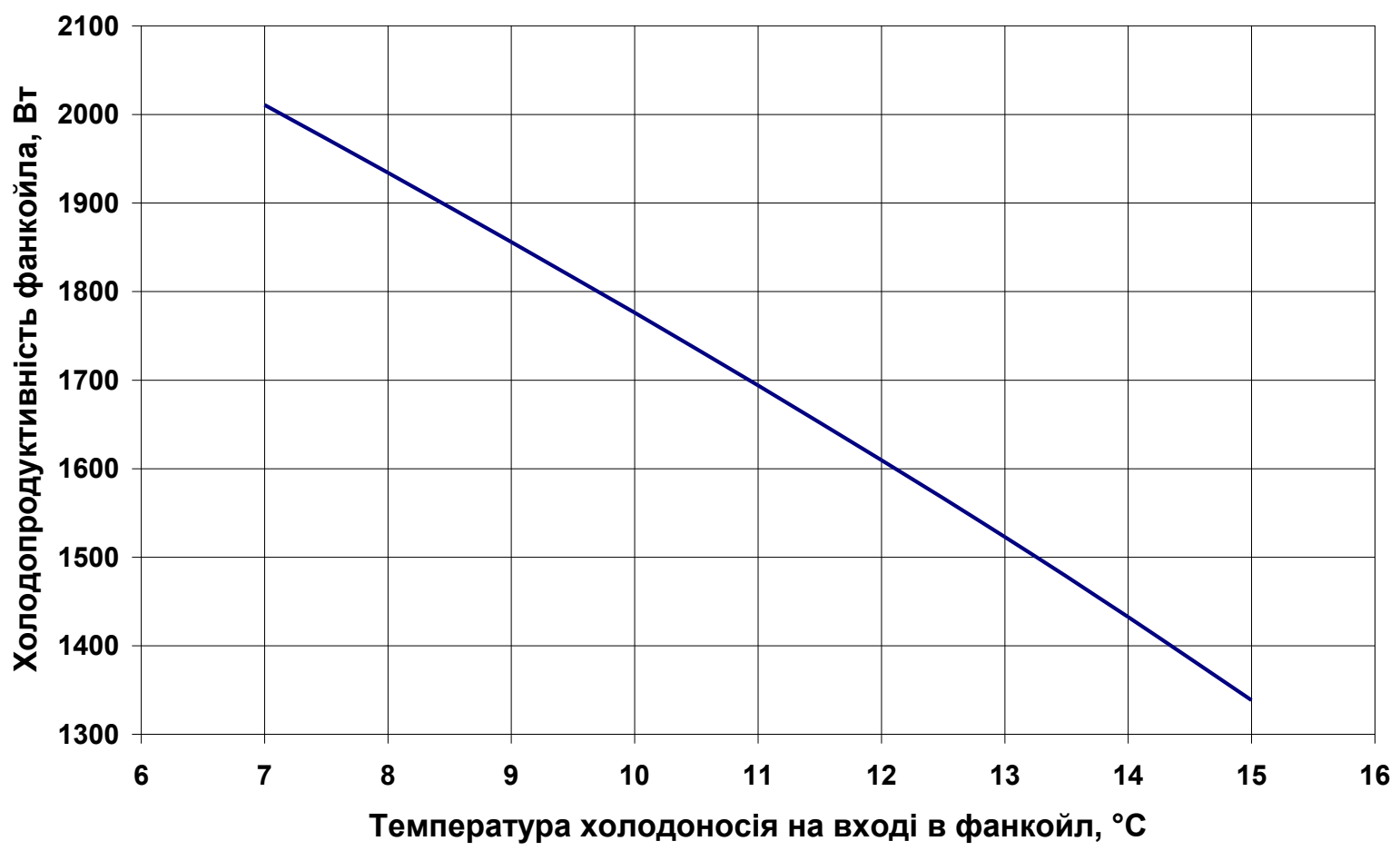

Рис. 6. Розрахункова залежність холодопродуктивності від температури холодоносія на вході в фанкойл.

Fig. 6. The calculated dependence of cooling capacity on the temperature of the coolant at the inlet to the fancoil.

Для виявлення реальних експлуатаційних характеристик фанкойлу були проведені натурні випробування системи «пасивного» кондиціонування (рис. 1). Методика випробувань полягала в наступному. Бак-акумулятор 3 попередньо наповнювали водою з видобувної свердловини 1. Для цього відкривали вентилі XX і включали свердловинний насос PP. Після заповнення бакаакумулятора насос РР вимикали і вентилі XX закривали. При проведенні досліджень по охолодженню приміщення відкривали вентилі ВВ i включали циркуляційний насос ПН. При цьому холодна вода 3 бака-акумулятора надходила в фанкойл 10 і охолоджувала повітря в приміщенні 9. Після проходу через фанкойл підігріта вода закачувалася в приймальню свердловину 2. В процесі експерименту вимірювалися температури холодоносія на вході/виході фанкойлу, а також температура повітря в приміщенні. Температура холодоносія вимірювалась за допомогою лічильника тепла Ultraheat T230-B36C-UA00-P 0H, а температура повітря в приміщенні - за допомогою контролера 3 виносним датчиком температури.

Результати замірів експериментальних параметрів.

Дебіт води на виході $з$ підйомної свердловини $0,9 \kappa г / \mathrm{c}$.
Швидкість наповнення баку-акумулятору 0,5 год.

Дебіт води, яка надходить на фанкойл - 0,06кг/с.

Температура води, яка надходить до бакуакумулятору $-12^{\circ} \mathrm{C}$.

Температура води, що надходить до фанкойлу $12,5^{\circ} \mathrm{C}$.

Початкова температура в приміщенні $-28^{\circ} \mathrm{C}$.

Температура води після охолодження приміщення $-23^{\circ} \mathrm{C}$.

Час зміни температури в приміщення - 0,5 год.

Площа охолодження приміщення $-20 \mathrm{~m}^{2}$.

Висота охолодження приміщення $-3 \mathrm{M}$.

Продуктивність вентиляторів - $340 \mathrm{~m}^{3} /$ год.

Холодопродуктивність - 2020 Вт.

Теплопродуктивність - 3030 Вт.

Об'єм протоку води - 348 кг/год.

Вхідна потужність вентилятору -37 Вт.

Кількість баків-акумуляторів - 7 шт.

Об'єм баків-акумуляторів -7 м $^{3}$.

Експериментальні дослідження системи «пасивного кондиціонування здійснювалися в денний час протягом 6 годин (з 10.00 до 16.00). У процесі проведення експерименту кожні 30 хвилин вимірювалися температури холодоносія на вході до фанкойлу, на виході з фанкойлу, а також температура повітря в приміщенні на 
висоті 1,5 м від підлоги. На рис. 7 показані експериментальні дані зміни значень цих показників у часі. 3 графіку експериментальних даних видно, що при постійній температурі на вході до фанкойлу $12,5^{\circ} \mathrm{C}$ температура в приміщенні знижувалася зі швидкістю близько $1,3^{\circ} \mathrm{C}$ в годину і через 4 години роботи фанкойлу стабілізувалася на рівні $23,5^{\circ} \mathrm{C}$. Ступінь нагріву холо- доносія у фанкойлі плавно змінювалася від $9^{\circ} \mathrm{C}$ в початковий момент до $4,5^{\circ} \mathrm{C}$ в кінці експерименту. Холодопродуктивність фанкойлу при цьому зменшилася з 3640 Вт до 1820 Вт. Результати натурних випробувань показали, що розбіжність експериментальних значень температурних і теплових характеристик фанкойлу з розрахунковими значеннями не перевищує 5-7\%.

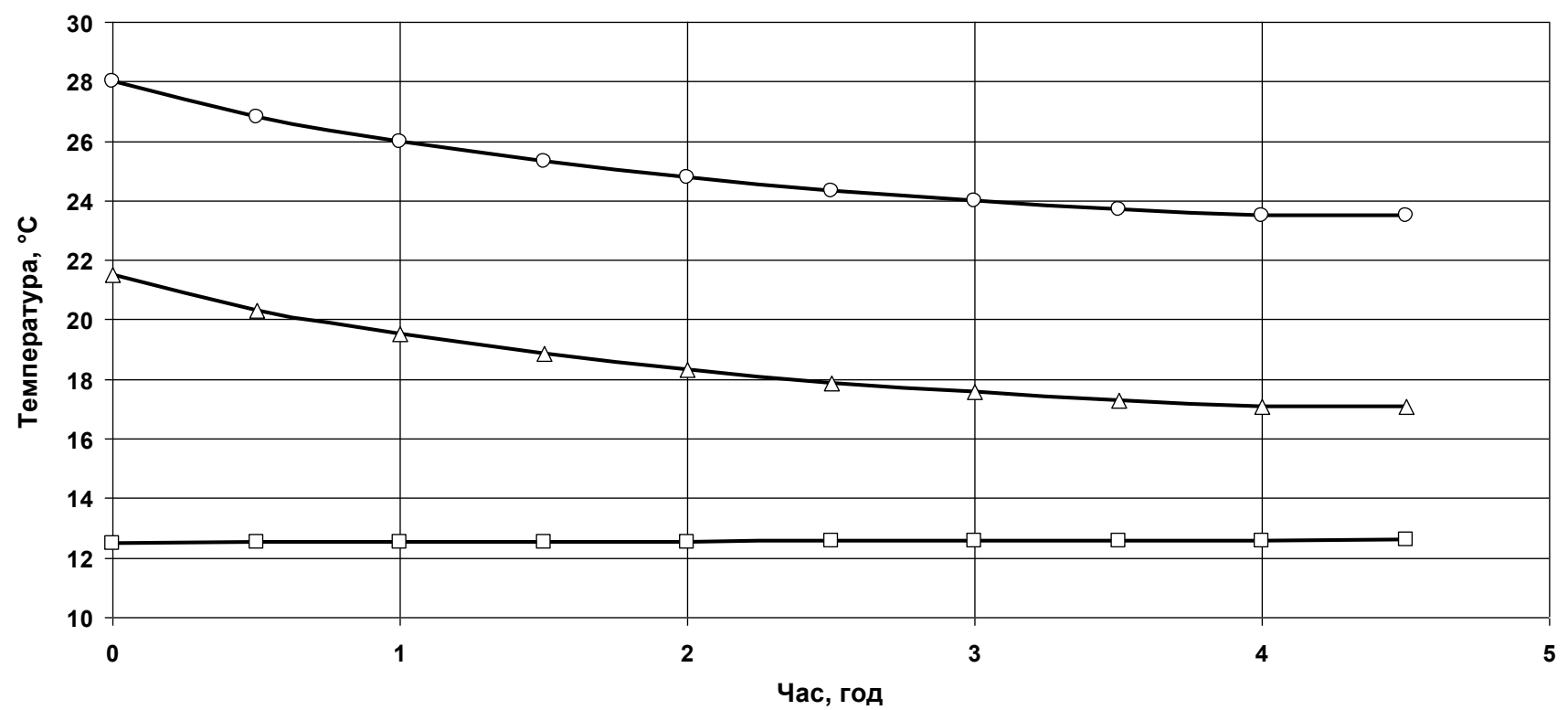

Рис. 7. Експериментальні значення температурних показників системи «пасивного» кондиціонування:

- - - температура холодоносія на вході в фанкойл;

$-\Delta--$ температура холодоносія на виході з фанкойлу;

—-_- температура повітря в приміщенні.

Fig. 7. Experimental values of temperature indicators of the system of "passive" conditioning:

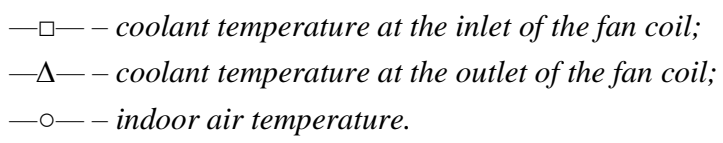

Висновки. 1. Система акумулювання води підземних горизонтів з початковою температурою води $12^{\circ} \mathrm{C}$ ефективно працює в режимі охолодження приміщення з застосуванням серійних фанкойлів.

2. Акумулятори теплоти у вигляді баківакумуляторів ефективно використовуються в якості буферних ємностей для регулювання подачі води в фанкойли.

3. В баках-акумуляторах при вистойці води більше 2-х діб спостерігається накопичення твердих осадів.

4. Система потребує подальшої модернізації для автоматичного заміру параметрів води і температури та вологості приміщення.

Стаття підготовлена в рамках виконання на- укового проекту «Геотерм-3» відомчої тематики та наукового проекту Цільової програми наукових досліджень Відділення фізико-технічних проблем енергетики НАН України «Фундаментальні дослідження процесів перетворення та використання енергії» «Енергодім».

1. Шевченко О.Г. Вразливість урбанізованого середовища до зміни клімату. Фізична географія та геоморфологія. 2014. Вип. 4. С. 112-120.

2. Inayat A., Raza M. District cooling system via renewable energy sources: A review. Renewable and Sustainable Energy Reviews. June. 2019. V. 107. Pp. 360-373.

3. Ampofo F., Maidment G.G., Missenden J.F. Review of groundwater cooling systems in London. Applied Thermal Engineering. 2006. V. 26. Pp. 2055-2062. 
4. Kuo C., Liao H. The feasibility of using circulating groundwater as renewable energy sources for air-conditioning in Taipei basin. Renewable Energy. 2012. V. 39. Pp. 175-182.

5. Морозов Ю.П. Добыча геотермальных ресурсов и аккумулирование теплоты в подземных горизонтах. Монография. Киев. Наукова думка. 2017. 198 с.

6. Морозов Ю.П., Величко В.В., Кушнір І.О. Оцінка теплового потенціалу верхніх шарів землі на території України. Відновлювана енергетика. 2018. № 4(55). С. 84-92.

7. Величко B.B. Охолодження повітря в приміщенні в літній період за допомогою фанкойлу та вертикальної свердловини. Матеріали XVII міжнародної науковопрактичної конференції "Відновлювана енергетика та енергоефективність у XXI столітті". Київ. 29-30 вересня 2016 р. C. $486-489$.

8. Нестеренко А.В. Основы термодинамических расчетов вентиляции и кондиционирования воздуха. М. Высш. шк. 1971. 459 с.

9. Ривкин С.Л., Александров А.А. Термодинамические свойства воды и водяного пара. М. Энергоатомиздат. 1984. $80 \mathrm{c}$.

10. Сычев В.В., Вассерман А.А., Козлов А.Д. и др. Термодинамические свойства воздуха. М. Изд-во стандартов. $1978.276 \mathrm{c}$.

11. Снєжкін Ю.Ф., Чалаєв Д.М., Дабіжа Н.О. Аналіз енергетичних показників процесу теплонасосного сушіння Промислова теплотехніка. -017. Т. 39. №3. С. 47-52.

12. Галайда Л. Потолочное охлаждение помещения как альтернатива кондиционированию. AWTherm. 2018. № 2. C. $82-86$.

\section{REFERENCES}

1. Shevchenko O.G. Vrazlyvist urbanizovanoho seredovyshcha do zminy klimatu. [Vulnerability of the urban environment to climate change]. Fizychna heohrafiia ta heomorfolohiia. 2014. V. 4. Pp. 112-120. [in Ukrainian].

2. Inayat A., Raza M. District cooling system via renewable energy sources: A review. Renewable and Sustainable Energy Reviews. June. 2019. V. 107. Pp. 360-373. [in English].

3. Ampofo F., Maidment G.G., Missenden J.F. Review of groundwater cooling systems in London. Applied Thermal Engineering. 2006. V. 26. Pp. 2055-2062. [in English].

4. Кио C., Liao $H$. The feasibility of using circulating groundwater as renewable energy sources for air-conditioning in Taipei basin. Renewable Energy. 2012. V. 39. Pp. 175-182. [in English].

5. Morozov Yu.P. Dobycha geotermalnykh resursov i akkumulirovaniye teploty $\mathrm{v}$ podzemnykh gorizontakh. [Extraction of geothermal resources and accumulation of heat in underground horizons]. Kyiv. Naukova Dumka. 2017. 198 p [in Ukrainian].

6. Morozov Yu.P., Velychko V.V., Kushnir I.O. Otsinka teplovoho potentsialu verkhnikh shariv Zemli na terytorii Ukrainy. [Estimation of thermal potential of the upper Earth's layers in Ukraine]. Vidnovluvana energetika. 2018. No. 4(55). Pp. 84-92. [in Ukrainian].

7. Velychko V.V. Okholodzhennia povitria $\mathrm{v}$ prymishchenni v litnii period za dopomohoiu fankoilu ta vertykalnoi sverdlovyny. [Cooling indoor air in the summer through fan coil and vertical borehole]. Materials XVII international conference Renewable energy and energy efficiency of the XXI century. 2016. Pp. 486-489. [in Ukrainian].
8. Nesterenko A.V. Osnovyi termodinamicheskih raschetov ventilyatsii i konditsionirovaniya vozduha. [Fundamentals of thermodynamic calculations of ventilation and air conditioning]. M. Vyisshaya shkola. 1971. 459 p. [in Russian].

8. Rivkin S.L., Aleksandrov A.A. Termodinamicheskie svoystva vodyi i vodyanogo para. [Thermodynamic properties of water and water vapor]. M. Energoatomizdat. 1984. 80 p. [in Russian].

9. Syichev V.V., Vasserman A.A., Kozlov A.D. $i$ dr. Termodinamicheskie svoystva vozduha. [Thermodynamic properties of air]. M. Izdatelstvo standartov. 1978. 276 p. [in Russian].

10. Sniezhkin Yu.F., Chalaiev D.M., Dabizha N.O. Analiz enerhetychnykh pokaznykiv protsesu teplonasosnoho sushinnia. [Analysis of energy performance of the process of heat pump drying]. Promyslova teplotekhnika. 2017. V. 39. No. 3. Pp. 4752. [in Ukrainian].

11. Galayda L. Potolochnoe ohlazhdenie pomescheniya kak alternativa konditsionirovaniyu. [Room ceiling cooling as an alternative to air conditioning]. AWTherm. 2018. No. 2. Pp. 8286. [in Russian].

\section{ЭКСПЕРИМЕНТАЛЬНОЕ ИССЛЕДОВАНИЕ СУТОЧНОГО АККУМУЛИРОВАНИЕ ХОЛОДА ПУТЕМ ИСПОЛЬЗОВАНИЯ ВОДЫ ПОДЗЕМНЫХ ГОРИЗОНТОВ Г. КИЕВА}

Ю.П.Морозов ${ }^{1}$, доктор технических наук, Д.М.Чалаев ${ }^{1,2}$, кандидат технических наук, В.Г.Олейниченко ${ }^{1}$,

\section{В.В.Величко}

${ }^{1}$ Институт возобновляемой энергетики НАН Украины, 02094, г. Киев, ул. Гната Хоткевича, 20A

${ }^{2}$ Институт технической теплофизики НАН Украины 03057, г. Киев, ул. Марии Капнист (Желябова), 2а

Изложены результаты экспериментального исследования эффективности использования суточного аккумулятора холодной воды для обеспечения работы серийных фанкойлов с ичелью обеспечения кондиционирования воздуха в отдельном помещении.

Натурная экспериментальная установка содержит добычную скважину, нагнетательную скважину, баки аккумуляторы, расходомер, термометр холодной воды, термометр воздуха в помещении, сетевой насос, термометр отработанной воды, помещения для охлаждения, фанкойл.

Вода с температурой $12^{\circ} \mathrm{C}$ из добычной скважины подается скважинным насосом в группу накопительных баков, которые являются аккумулятором холода. После накопления воды в баках включается сетевой насос, который подает воду из накопительных баков в фанкойльл. Вода, промедмая через фанкойль и отдавмая холод в помещение, поступает в нагнетательную скважину.

Целью эксперимента является исследование системы аккумулирования холодной воды в качестве суточного аккумулирования холода и дальнейшего использования для обеспечения комфортных условий в помещуении с помощьью серийных фанкойлов.

Основные характеристики проведения эксперимента: дебит водьл на выходе из подъемной скважинь составляет 0,9 кг/с, дебит воды, поступающуей на фанкойл - 0,1 кг/c, расход воздуха через фанкойл - $340 \mathrm{M}^{3} / 4$, температура 
воды, поступающей в бак-аккумулятор $-12^{\circ} \mathrm{C}$, температура воды, поступающей в фанкойль $-12,5^{\circ} \mathrm{C}$, площадь охлаждения помещения - $20 \mathrm{M}^{2}$, начальная температура в помещении $-28^{\circ} \mathrm{C}$, количество баков-аккумуляторов - 7 шт., общий объем баков-аккумуляторов- $7 \mathcal{M}^{3}$.

$B$ результате проведенных экспериментов достигнуто снижение температуры в помещении до $23^{\circ} \mathrm{C}$ за 3 часа работы фанкойла. Установлено, в проиессе охлаждения помещения холодопроизводительность фанкойла менялась от 3640 Bт в начальный период до 1820 Вт в конце. Температуры хладоносителя на выходе из фанкойла при этом составили соответственно $21,5^{\circ} \mathrm{C}$ и $17,1^{\circ} \mathrm{C}$.

Исследования показали, что система аккумулирования воды подземных горизонтов с начальной температурой воды $12^{\circ} \mathrm{C}$ эффективно работает в режиме охлаждения помещения с применением серийных фанкойлов. Аккумуляторы теплоты в виде баков-аккумуляторов эффективно используются также в качестве буферных емкостей для регулирования подачи воды в фанкойльл. В баках-аккумуляторах при выстойке воды более 2-х суток наблюдается накопление твердых осадков. Расхождение расчетных значений температуры с экспериментальными значениями не превыпает 5-7\%. Система нуждается в дальнейшей модернизачии для автоматического измерения параметров воды и температуры и влажности помещения. Библ. 13, рис. 7.

Ключевые слова: аккумулятор холодной воды, добычная скважина, нагнетательная скважина, фанкойл, кондиционирование помещений, бак-аккумулятор, сетевой насос

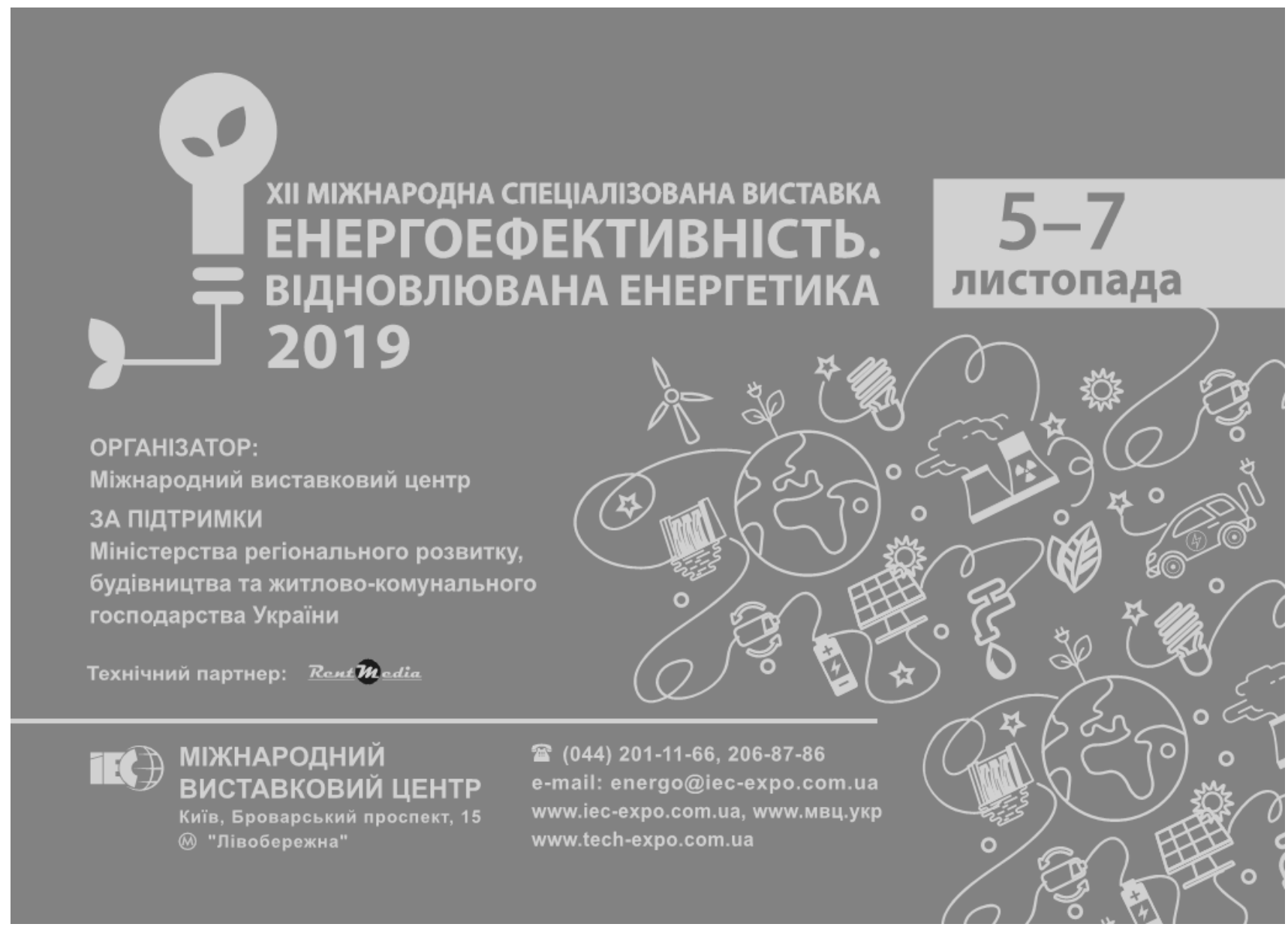

